\title{
Productivity is negatively related to shoot growth across five mango cultivars in the seasonally wet-dry tropics of northern Australia
}

\author{
Ping Lu ${ }^{1,2 *}$, Elias K. ChACKo ${ }^{1+}$, Sean L. BitheLL ${ }^{3}$, Heinz SCHAPER ${ }^{1,4}$, Josef WiebeL ${ }^{1,5}$, Steve ColE $^{1,6}$, Warren J. MüLleR ${ }^{7}$
}

${ }^{1}$ CSIRO Plant Ind., PMB 44, Winnellie, Darwin, NT 0822 Australia

2 Present address: Energy Res. Aust. Ltd., GPO Box 2394, Darwin 0800, North. Territ., Australia

ping.lu@riotinto.com

${ }^{3}$ Plant Ind., Dep. Prim. Ind.

Fish., North. Territ. Gov., GPO Box 3000, Darwin, NT 0801, Australia

${ }^{4}$ Present address: YARA GmbH \& Co, KG Hanninghof 35, D-48249 Dülmen, Germany

${ }^{5}$ Present address: K+S KALI $\mathrm{GmbH}$, Bertha-von-SuttnerStraße 7, 34131 Kassel, Germany

${ }^{6}$ Present address: Navy Strateg. Command, R1-4-B160, Russell Off. Canberra ACT, Australia

${ }^{7}$ CSIRO Math. Inform. Stat., GPO Box 664, Canberra ACT 2601, Australia

+ Deceased August 21, 1997

* Correspondence and reprints

Received 16 March 2012 Accepted 16 May 2012

Fruits, 2013, vol. 68, p. 279-289 (C) 2013 Cirad/EDP Sciences All rights reserved

DOI: $10.1051 /$ fruits/2013074

www.fruits-journal.org

RESUMEN ESPAÑOL, p. 289
Productivity is negatively related to shoot growth across five mango cultivars in the seasonally wet-dry tropics of northern Australia.

Abstract - Introduction. Mango productivity is low in seasonally wet-dry tropical areas where breeding programs require information on factors affecting productivity of mango cultivars. Specifically, our study tested a novel hypothesis that, among Australian- and Florida-bred cultivars, the greater growth of vegetatively vigorous cultivars would contribute to lower levels of fruit production in comparison with less vegetatively vigorous cultivars, in a wet-dry tropical environment. Materials and methods. A field experiment was conducted on trees of the cultivars 'Kensington Pride' and 'Strawberry', both polyembryonic cultivars, and 'Haden', 'Irwin' and 'Tommy Atkins', all monoembryonic cultivars. Results. Shoot growth was recorded over two years; in both years the polyembryonic cultivars produced more new shoot length than the monoembryonic cultivars; 'Irwin' was the least vigorous cultivar in both years. Across cultivars, there was a negative relationship between normalised (by flowering intensity and canopy area) fruit number or yield and vegetative vigour as represented by new shoot length. Conclusion. The results supported the hypothesis that the greater shoot growth of vegetatively vigorous cultivars contributed to lower levels of fruit production in comparison with less vegetatively vigorous cultivars in a tropical environment. This is the first study which demonstrates that the extent of seasonal shoot growth had a fruit production cost for mango.

Australia / Mangifera indica / yields / vigour / variety trials / polyembryony / monoembryony

La productivité est négativement liée à la croissance des rameaux pour cinq cultivars de manguier sous climat tropical à saisons humides et sèches du nord de I'Australie.

Résumé - Introduction. La productivité du manguier est faible dans les régions tropicales à saisons humides et sèches où les programmes d'amélioration auraient besoin d'informations sur les facteurs affectant la productivité des cultivars. Plus précisément, notre étude a testé une nouvelle hypothèse selon laquelle, parmi des cultivars sélectionnés en Australie et en Floride, plus grande serait la croissance végétative des cultivars vigoureux, plus faible serait leur production fruitière par rapport à des cultivars végétativement moins vigoureux, dans un environnement tropical à saisons humides et sèches. Matériel et méthodes. Une expérience a été menée en verger sur des manguiers 'Kensington Pride' et 'Strawberry', deux cultivars polyembryoniques, et 'Haden', 'Irwin' et 'Tommy Atkins', cultivars monoembryonnés. Résultats. La croissance des rameaux a été enregistrée sur deux ans ; au cours de ces deux années, les cultivars polyembryoniques ont produit de nouveaux rameaux plus longs que les cultivars monoembryonnés ; 'Irwin' a été le cultivar le moins vigoureux pendant ces deux années. Parmi les cultivars, il est apparu une relation négative entre le nombre et la production de fruits normalisés (par rapport à l'intensité de la floraison et le volume de la canopée) et la vigueur végétative, représentée par la longueur des nouveaux rameaux. Conclusion. Les résultats confirment l'hypothèse selon laquelle une plus grande croissance des rameaux des cultivars végétativement vigoureux contribuerait à une production moindre de fruits par rapport aux cultivars végétativement moins vigoureux dans un environnement tropical. C'est la première étude qui démontre que l'ampleur de la croissance des rameaux de saison peut impacter le volume de production des manguiers.

Australie / Mangifera indica / rendement / vigueur / essai de variété / polyembryonie / monoembryonie 


\section{Introduction}

Despite decades of research on mango crop improvement and orchard management practices, the problem of low orchard efficiency in mango (Mangifera indica L.) remains for the world's fourth largest fruit crop $[1,2]$.

The Australian mango industry has approx. 1.3 M trees planted, and the industry in the seasonally wet-dry tropics of the Northern Territory of north Australia is annually worth $46 \mathrm{M}$ Australian dollars [3] ${ }^{1}$. It is mainly based on a single polyembryonic cultivar, Kensington Pride (Kensington Pride), which shares about $70 \%$ of production. The predominance of Kensington Pride in Australia is due to consumer preference, although this cultivar has production problems including erratic bearing, over-vigorous growth and low yields [4-6].

It is well established that exposure to low temperatures $\left(<\sim 15^{\circ} \mathrm{C}\right)$ promotes floral induction in mango, but for mango grown in the hot tropics this induction cue may be rarely attained or only occurs for short periods, and the age of shoot tissue is an important inductive factor [1, 7]. Hot tropical climates also provide an environment which promotes vegetative flushing [8]. Studies in the wet-dry tropics of the Northern Territory have shown that environmental factors such as high vapour pressure levels and drought stress reduce photosynthesis in Kensington Pride, yet despite these limitations Kensington Pride in this environment produces up to four vegetative flushes per season, including some flushes during flowering and early fruit growth [9-11].

Studies of mango showed that starch concentrations in the roots and wood are depleted to minimum concentrations during fruit growth [12] and that stored assimilate was important for fruit production, by demonstration that current assimilate was

${ }^{1}$ Moore C., Mango season, Dep. Res., NT Gov., Darwin, Aust, 2009, http://www.nt. gov.au/d/Primary_Industry/Content/File/ horticulture/mango/2009\%20Mango\%20 Season\%20Overview.pdf, Date access. 26-52010, 2009. insufficient to support fruit growth [13]. In Macadamia, another vigorous evergreen species, competition between new shoot growth and fruit production has been shown to reduce yield by new shoot growth following pruning increasing fruitlet abscission [14]. These studies suggest that when shoot growth in Kensington Pride occurs that growth may directly or indirectly affect yield through demands on current or stored assimilate. These effects could also be relevant to other mango cultivars, as a negative relationship between total shoot length and productivity was reported for a group of biennial-bearing Indian monoembryonic cultivars [15].

Although the use of paclobutrazol has improved flowering and fruit production of Kensington Pride in this wet-dry tropical north Australian environment, fruit production has remained low and ranges from (5.2 to 14.5$) \mathrm{t} \cdot \mathrm{ha}^{-1}$ per year $[10,16]$ and, although the vegetative vigour of Kensington Pride in this wet-dry tropical environment has been reported $[9,10]$, there has been no evaluation of the possible effects of vigour on productivity in comparison with other cultivars. In this environment, more productive cultivars are required but there is an absence of information on specific tropical environmental factors affecting mango productivity to guide breeding or selection programs. Due to the long period between the planting of fruit trees and when the trees will produce fruit, we made use of data from a historic experiment of five mango cultivars (including mono- and polyembryonic cultivars). These historic data provided the basis of an initial investigation of the effects of vigour and shoot growth from which further contemporary studies could be developed. The specific hypothesis addressed was that in a tropical environment the greater growth of vegetatively vigorous cultivars would contribute to lower levels of fruit production in comparison with less vegetatively vigorous cultivars. This information will provide improved knowledge of the potential costs of vigour in tropical mango production and provide additional productivity-related selection criteria for cultivars for semi-arid tropical environments. 
Table I.

Long-term monthly averages (LTA 1941-2011) of Darwin (Australia) rainfall (mm, Aust. Gov., Bureau Meteorol., site no. 14015) for months with a long-term average rainfall higher than $10 \mathrm{~mm}$ (September-May), and monthly rainfall recorded in the months preceding the three fruit production seasons of 1988, 1989 and 1990.

\begin{tabular}{lcccccccccc}
\hline Period & Sept. & Oct. & Nov. & Dec. & Jan. & Feb. & Mar. & Apr. & May & Total \\
\hline $1987-88$ & 21.8 & 2.4 & 104.0 & 539.2 & 233.4 & 277.8 & 334.6 & 19.6 & 74.8 & 1607.6 \\
$1988-89$ & 48.8 & 161.8 & 248.0 & 402.8 & 267.8 & 161.8 & 573.8 & 184.6 & 4.0 & 2053.4 \\
$1989-90$ & 0 & 25.0 & 40.2 & 221.4 & 305.0 & 152.8 & 219.4 & 151.0 & 59.6 & 1174.4 \\
LTA & 15.8 & 70.0 & 140.0 & 252.4 & 426.2 & 356.6 & 319.0 & 100.3 & 21.1 & 1710.4
\end{tabular}

\section{Materials and methods}

\subsection{Experimental trees and growing environment}

A field experiment was conducted over three years from 1988 to 1990 on four-yearold mango trees (in 1988) in an orchard in Humpty Doo near Darwin $\left(12^{\circ} \mathrm{S}, 130^{\circ} \mathrm{E}\right.$, $13 \mathrm{~m}$ above sea level), in the wet-dry tropics of the Northern Territory, Australia. The soil was massive 'red earth' derived from laterite rocks; these soils are free-draining, have a sandy-loam texture and high gravel content, and are extremely poor in all major and minor elements and organic matter [17].

In Darwin, long-term mean maximum monthly air temperatures range from $30.5^{\circ} \mathrm{C}$ to $33.3^{\circ} \mathrm{C}$ with daily maxima over $30^{\circ} \mathrm{C}$ in the coolest months of June-July and $34^{\circ} \mathrm{C}$ for the hottest month of November ${ }^{2}$. The long-term mean minimum monthly temperatures range from (19.3 to 25.3$){ }^{\circ} \mathrm{C}^{2}$ and temperatures in the three seasons of our study were representative of these longterm average temperatures (data not presented). From June to August (dry season) no effective rain usually falls and relative humidity is low ( $<50 \%$ at midday). During the wet season, including the pre-monsoonal and post-monsoonal transition rainy periods (September to May), the climate in Darwin is humid and hot, with an annual rainfall of $1723 \mathrm{~mm}$ (mean 1941-2011) ${ }^{2}$.

\footnotetext{
${ }^{2}$ Anon., Monthly climate statistics, Darwin airport (station number 014105, 1941-2011), Bureau Meteorol., Aust. Gov., http://www. bom.gov.au/climate/data/ Date access. 23/6/ 2012, 2012.
}

Monthly rainfall for the three years of the experiment and the long-term averages were recorded (table I).

The experimental trees were ten uniform trees each of the polyembryonic cultivars Kensington Pride and Strawberry, and the monoembryonic cultivars Haden, Irwin and Tommy Atkins, grafted onto unselected seedlings of Kensington Pride. Trees were planted in an orchard at $10 \mathrm{~m} \times 10 \mathrm{~m}$ spacing, with the 50 trees assigned completely randomly to positions. Throughout the study (1988-1990) the tree canopies were not in contact and no pruning occurred due to the young age of the trees. At the time of harvest in 1988, 1989 and 1990 the number of commercial-grade fruit from each tree was recorded. Fruit weights were recorded at harvest in the 1990 season only. The 1989 yields were estimated using the fruit number and average fruit weight from the 1990 season for each cultivar. In 1988 and 1989, after recording fruit numbers, thirty fruited shoots on each tree were tagged with numbered flagging tape for post-season observations of the flushing pattern, new shoot length, and intensity of flowering and fruiting in the 1989 and 1990 seasons, respectively. In October 1990, the height, stem diameter and radius of the canopy of the trees were recorded and canopy surface area (CSA) was estimated as $3 / 4$ of a sphere.

The trees were irrigated according to the normal orchard irrigation practice in the region which involved drought-stressing the trees by withholding irrigation from the end of the wet season until flowering in late June or early July [7]. Following flowering, under-tree micro-sprinkler irrigation 
(600-800 L per tree) was applied at 3-4-day intervals; the sprinklers wet the whole of the soil surface under the canopy. Irrigation was stopped at harvest in October. More information on soil water conditions and fertilisation can be found in Lu et al. [11].

\subsection{Data processing and analysis}

To examine the relationship between new shoot length and aspects of yield among cultivars each year, the estimated yield (fruit kg per tree) for 1989 and actual yield for 1990 were separately normalised by calculating the flowering canopy surface area as [(canopy area $) \times(\%$ flowering shoots $)]$, then dividing yield by the flowering canopy surface area. The normalised yield is then in $\mathrm{kg} \cdot \mathrm{m}^{-2}$ flowering canopy surface area. The same approach was used for normalised fruit number for the 1989 and 1990 seasons [fruit number / (canopy area) $\times(\%$ flowering shoots)] to provide no. of fruit per $\mathrm{m}^{2}$ flowering canopy surface area.

Overall significances of differences in responses among the five cultivars were determined using one-way analyses of variance. Differences among individual cultivars were determined by deriving least significant differences (LSD) at the 5\% probability level from these analyses.

\section{Results}

\subsection{Tree size and vegetative growth}

Among the five cultivars, the cv. Kensington Pride was the most vigorous, with the largest canopy surface area, stem diameter and tree height at the end of the trial (table II). In contrast, Irwin and Tommy Atkins had the smallest canopy surface area, tree height and stem diameter.

Flushing activity varied between 1989 and 1990. The average percentage of the shoots flushed was about 80\% in 1989 regardless of cultivar, but only $35-55 \%$ in 1990 (table III). Reduced flushing was associated with a lower monsoonal wet season rainfall in 1989-1990 (1174 mm, including the pre-monsoonal and post-monsoonal rainy periods, September to May) compared with $2053 \mathrm{~mm}$ for the 1988-1989 season and the long-term average $(1710 \mathrm{~mm})$ (table I). In 1989, on average, all cultivars had about double the number of flushes observed in 1990 (table IV). Over the two years, Tommy Atkins had the least flushes per shoot while Haden had the most flushes per shoot.

In 1990, new shoots were significantly shorter than in 1989 for Kensington Pride, Tommy Atkins and Irwin, but did not differ in length for Strawberry and Haden (table IV). Kensington Pride and Strawberry had significantly longer new shoots (averages $127-175 \mathrm{~mm}$ and $122-137 \mathrm{~mm}$, respectively) than the other cultivars, among which Irwin had the least new growth (average $64-82 \mathrm{~mm}$ ).

\subsection{Flowering, fruiting and yield}

In 1989, the mango cultivars Kensington Pride and Strawberry had the highest percentage of flowering shoots (67\% and $73 \%$ ), while Haden had the lowest percentage (12\%) (table IV). In 1990, Haden had the highest flowering in conjunction with Kensington Pride. Flowering for Strawberry in 1990 was the inverse of 1989 (73\%) and had the lowest percentage (27\%). Tommy Atkins and Irwin consistently had about 40\% of flowering shoots in both seasons.

In 1990, there was no significant difference among cultivars in the percentage of flowered shoots that bore fruit (table V). However, the number of fruit per flowering shoot varied significantly among cultivars; Kensington Pride bore the least fruits (1.2 fruits per flowered shoot), while Irwin and Haden bore the most fruit (2.6 and 2.2, respectively). On the basis of all tagged shoots, Haden, Kensington Pride and Irwin had the highest percentage (28-37\%) of shoots bearing fruit, while Strawberry had the lowest percentage (14\%). Haden and Irwin had significantly higher fruit numbers for all tagged shoots $(0.83$ and 0.71 , respectively) than Strawberry (0.25), Kensington Pride (0.35) and Tommy Atkins (0.51).

Over the three years of the experiment, the number of fruit harvested per tree varied 
Table II.

Tree characteristics for five mango cultivars in October 1990 (Australia). Means are over 10 trees per cultivar.

$\begin{array}{lccc}\text { Mango } & \text { Canopy surface area } & \text { Stem diameter } \\ \left(\mathrm{m}^{2}\right) & \begin{array}{c}\text { Tree height } \\ (\mathrm{mm})\end{array} & 4.63 \mathrm{a} \\ \text { cultivar } & 89 \mathrm{~b} & 200 \mathrm{a} & 3.17 \mathrm{c} \\ \text { Haden } & 45 \mathrm{c} & 154 \mathrm{~b} & 4.75 \mathrm{a} \\ \text { Irwin } & 108 \mathrm{a} & 200 \mathrm{a} & 4.00 \mathrm{~b} \\ \text { Kensington Pride } & 80 \mathrm{~b} & 151 \mathrm{~b} & 3.33 \mathrm{c} \\ \text { Strawberry } & 46 \mathrm{c} & 142 \mathrm{~b} & 0.311 \\ \text { Tommy Atkins } & 5.8 & 13.3 & \begin{array}{l}\text { b } \\ \text { Standard error of the differences }\end{array}\end{array}$

Within each column, means followed by the same letter are not significantly different at the $5 \%$ level.

Table III.

Percentages of shoots in 1989 and 1990 with new flushes present and with multiple new flushes ( 2 or 3 ) for five mango cultivars (Australia). Means are over 10 trees per cultivar.

\begin{tabular}{lcccc}
\hline & \multicolumn{2}{c}{1989} & \multicolumn{2}{c}{1990} \\
Mango & New flushes & Multiple new flushes & New flushes & Multiple new flushes \\
\cline { 2 - 3 } Haden & $82.4 \mathrm{a}$ & $69.8 \mathrm{a}$ & $55.1 \mathrm{a}$ & $27.7 \mathrm{a}$ \\
Irwin & $78.7 \mathrm{a}$ & $51.7 \mathrm{ab}$ & $52.3 \mathrm{ab}$ & $15.0 \mathrm{ab}$ \\
Kensington Pride & $85.4 \mathrm{a}$ & $39.4 \mathrm{~b}$ & $49.9 \mathrm{ab}$ & $14.7 \mathrm{ab}$ \\
Strawberry & $82.3 \mathrm{a}$ & $53.3 \mathrm{ab}$ & $34.0 \mathrm{~b}$ & $17.4 \mathrm{ab}$ \\
Tommy Atkins & $76.4 \mathrm{a}$ & $1.3 \mathrm{c}$ & $39.8 \mathrm{ab}$ & $2.4 \mathrm{~b}$ \\
\hline $\begin{array}{l}\text { Standard error } \\
\text { of the differences }\end{array}$ & 6.12 & 7.48 & 8.02 & 5.05 \\
\hline Within each column & & &
\end{tabular}

Table IV.

Mean number of new flushes per shoot, mean new shoot length and mean flowering intensity (\% of flowering shoots) for five mango cultivars (Australia). Means are over 10 trees per cultivar.

\begin{tabular}{|c|c|c|c|c|c|c|}
\hline \multirow{2}{*}{$\begin{array}{l}\text { Mango } \\
\text { cultivar }\end{array}$} & \multicolumn{2}{|c|}{ No. new flushes per shoot } & \multicolumn{2}{|c|}{ New shoot length (mm) } & \multicolumn{2}{|c|}{$\%$ of flowering shoots } \\
\hline & 1989 & 1990 & 1989 & 1990 & 1989 & 1990 \\
\hline Haden & $1.59 \mathrm{a}$ & $0.84 a^{*}$ & $92 d$ & $99 \mathrm{~b}$ & $12 \mathrm{c}$ & $61 a^{*}$ \\
\hline Irwin & $1.31 \mathrm{~b}$ & $0.68 b^{*}$ & $82 \mathrm{~d}$ & $64 c^{*}$ & $41 \mathrm{~b}$ & $42 \mathrm{~b}$ \\
\hline Kensington Pride & $1.25 \mathrm{~b}$ & $0.66 \mathrm{bc}^{*}$ & $175 \mathrm{a}$ & $127 \mathrm{a}^{\star}$ & $67 \mathrm{a}$ & $62 \mathrm{a}$ \\
\hline Strawberry & $1.36 \mathrm{~b}$ & $0.54 \mathrm{~cd}^{*}$ & $137 \mathrm{~b}$ & $122 \mathrm{a}$ & 73 a & $27 c^{*}$ \\
\hline Tommy Atkins & $0.78 \mathrm{c}$ & $0.42 \mathrm{~d}^{*}$ & $115 \mathrm{c}$ & $95 b^{*}$ & $41 \mathrm{~b}$ & $40 \mathrm{~b}$ \\
\hline $\begin{array}{l}\text { Standard error } \\
\text { of the differences }\end{array}$ & 0.126 & 0.063 & 8.5 & 9.2 & 7.7 & 7.3 \\
\hline
\end{tabular}


Table V.

Fruiting pattern of the five mango cultivars in 1990 in relation to flowering performance (Australia). Means are over 10 trees per cultivar.

\begin{tabular}{lcccc}
$\begin{array}{l}\text { Mango } \\
\text { cultivar }\end{array}$ & $\begin{array}{c}\text { \% floral shoots with } \\
\text { fruit }\end{array}$ & $\begin{array}{c}\% \text { all types of shoot } \\
\text { with fruit }\end{array}$ & $\begin{array}{c}\text { No. of fruit per flowering } \\
\text { shoot }\end{array}$ & $\begin{array}{c}\text { No. of fruit per all types of } \\
\text { shoot }\end{array}$ \\
\hline Haden & $61 \mathrm{a}$ & $37 \mathrm{a}$ & $2.2 \mathrm{ab}$ & $0.83 \mathrm{a}$ \\
Irwin & $66 \mathrm{a}$ & $28 \mathrm{ab}$ & $2.6 \mathrm{a}$ & $0.71 \mathrm{a}$ \\
Kensington Pride & $48 \mathrm{a}$ & $30 \mathrm{ab}$ & $1.2 \mathrm{c}$ & $0.35 \mathrm{~b}$ \\
Strawberry & $52 \mathrm{a}$ & $14 \mathrm{c}$ & $1.8 \mathrm{~b}$ & $0.25 \mathrm{~b}$ \\
Tommy Atkins & $64 \mathrm{a}$ & $25 \mathrm{~b}$ & $2.0 \mathrm{~b}$ & $0.51 \mathrm{~b}$ \\
Standard error & 9.3 & 6.3 & 0.29 & 0.156 \\
of the differences & & &
\end{tabular}

Table VI.

Fruit production per tree of the five mango cultivars in 1988-1990 (Australia). Means are over 10 trees per cultivar. Yield values in 1989 were estimated using the fruit weight measured in 1990.

\begin{tabular}{|c|c|c|c|c|c|c|c|}
\hline \multirow{2}{*}{$\begin{array}{l}\text { Mango } \\
\text { cultivar }\end{array}$} & \multicolumn{4}{|c|}{ Number of fruit per tree } & \multirow{2}{*}{$\begin{array}{l}\text { Fruit weight } \\
\qquad(\mathrm{g}) \\
1990\end{array}$} & \multirow{2}{*}{$\begin{array}{c}\text { Estimated yield per tree } \\
(\mathrm{kg}) \\
1989\end{array}$} & \multirow{2}{*}{$\begin{array}{l}\text { Yield per tree } \\
\text { (kg) } \\
1990\end{array}$} \\
\hline & 1988 & 1989 & 1990 & 3-year mean & & & \\
\hline Haden & $212 a$ & $41 c$ & $143 b$ & $132 b$ & $406 a$ & $17 \mathrm{~b}$ & $58 \mathrm{~b}$ \\
\hline Irwin & $168 b$ & $138 \mathrm{a}$ & $148 b$ & $151 \mathrm{a}$ & $359 a$ & $50 \mathrm{a}$ & $53 \mathrm{~b}$ \\
\hline Kensington Pride & $109 \mathrm{c}$ & $117 \mathrm{~b}$ & $175 \mathrm{a}$ & $134 \mathrm{~b}$ & $420 \mathrm{a}$ & $49 a$ & $74 \mathrm{a}$ \\
\hline Strawberry & $161 b$ & $123 a b$ & $116 \mathrm{c}$ & $133 b$ & $203 b$ & $25 b$ & $24 c$ \\
\hline Tommy Atkins & $98 \mathrm{c}$ & $59 \mathrm{c}$ & $98 \mathrm{c}$ & $85 \mathrm{c}$ & $383 a$ & $23 b$ & $38 \mathrm{~b}$ \\
\hline $\begin{array}{l}\text { Standard error } \\
\text { of the differences }\end{array}$ & 14.8 & 17.3 & 20.2 & 10.0 & 18.2 & 6.1 & 7.4 \\
\hline
\end{tabular}

significantly from year to year in all cultivars except Irwin and Strawberry, although the values for Strawberry were quite variable (table VI). The cultivar Irwin had an average of 151 fruits per tree per year and a low coefficient of variation $(\mathrm{CV})$ at $10 \%($ table VI). The most variable cultivar was Haden, with 41 to 212 fruits per tree and a CV of 65\%. For the 3-year averages, Irwin had the highest number of fruit (151) per tree, which was significantly higher than Kensington Pride, Strawberry and Haden (at about 133 fruits per tree). Regression of fruit number against flowering intensity for each year was not significant; however, for the data pooled from both seasons this approached significance (multiple $R^{2}=0.37, P=0.061$, figure $1 A$ ). The cultivars Strawberry and Haden had large differences in flowering intensity among the years, with higher fruit numbers in the year with the more intense flowering. For pooled data for the 1989 and 1990 seasons, normalised fruit number (by flowering intensity and canopy size) was significantly negatively related to new shoot length (multiple $R^{2}=0.62, P=0.007$, figure $1 B$ ). Separate regressions for the two years did not achieve significance due to insufficient data points but were consistent with the overall relationship. For the 1990 season, when individual fruit weight was measured, Strawberry had significantly lighter fruit 

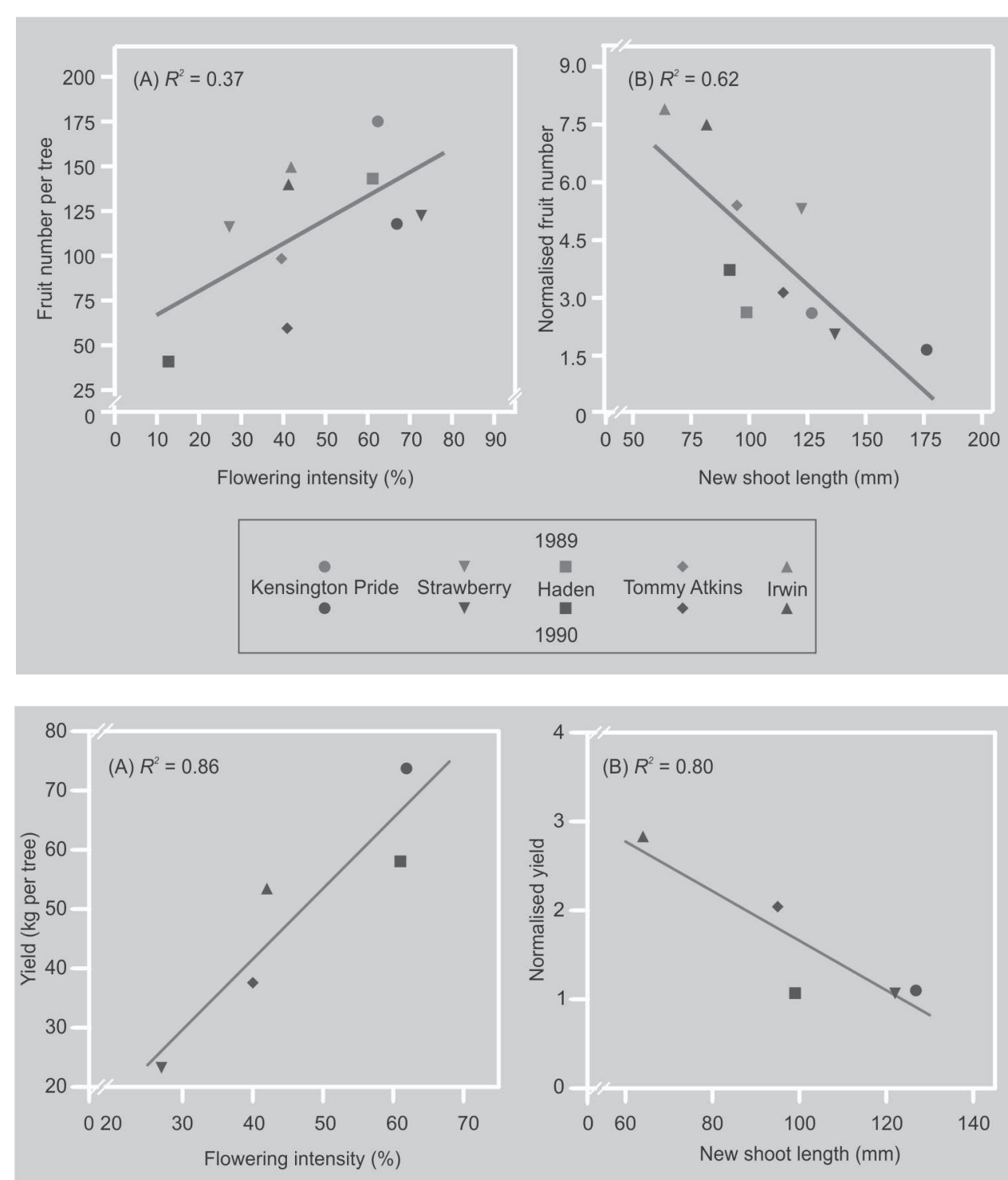

\begin{tabular}{|ccccc|}
\hline Kensington Pride & Strawberry & Haden & Tommy Atkins & Irwin \\
\hline
\end{tabular}

(203 g) than the other cultivars, which had similar weights (383 g to 420 g). In 1990, for yield per tree, Kensington Pride ( $74 \mathrm{~kg}$ per tree) had a significantly greater yield than Haden, Irwin and Tommy Atkins with yields of $38 \mathrm{~kg}$ to $58 \mathrm{~kg}$, and Strawberry had a significantly lower yield ( $24 \mathrm{~kg}$ per tree) than these cultivars. In 1989, when yields were estimated, Kensington Pride and Irwin had higher yields than the other three cultivars (table VI).

\section{Figure 1.}

A) Relationship between flowering intensity and the number of harvested commercial-grade fruit per tree for five mango cultivars in 1989 and 1990.

B) Relationship between new shoot length and the normalised fruit number (no. per $\mathrm{m}^{2}$ of flowering canopy surface area) in 1989 and 1990. In both $\mathrm{A}$ ) and $\mathrm{B}$ ), the solid line is the linear regression line.

\section{Figure 2.}

A) Relationship between flowering intensity and fruit yield for five mango cultivars in 1990.

B) Relationship between new shoot length and the normalised yield $\left(\mathrm{kg}\right.$ per $\mathrm{m}^{2}$ of flowering canopy surface area) in 1990.

In both $\mathrm{A}$ ) and $\mathrm{B}$ ), the solid line is the linear regression line. 
this relationship was also significant $\left(R^{2}=\right.$ 0.71 ), but not for estimated yield in 1989 only.

\section{Discussion}

\subsection{Vegetative vigour}

Mango cultivar studies often focus on aspects related to flowering and fruit production [18-20]. Yet reproductive structures arise from vegetative flushes, making the number or proportion of vegetative flushes to initiate, be induced, flower, set and maintain fruit through to harvest an integral measure of a cultivar's vegetative reproductive carbohydrate allocation and productivity.

New shoot length provides a useful index of vegetative vigour as it integrates the percentage of shoots flushed and number of flushes per shoot, including zero values for non-flushed shoots. The new shoot length results identified the polyembryonic Kensington Pride and Strawberry as more vigorous in both years than the three monoembryonic cultivars, Haden, Tommy Atkins and Irwin (table III). A growth room study of 10 mango cultivars showed a significant positive relationship between mean temperature and vegetative flushing as measured by shoot extension across cultivars; polyembryonic cultivars including Kensington Pride as a group were characterised by having the least growth in lowtemperature regimes [21]. Our finding of a greater investment in new shoot growth by the two polyembryonic cultivars may reflect a suitability for the lowland wet tropical environments which are considered the origin of polyembryonic mango [22]. However, it is unfortunate that this suitability is characterised by vegetative dominance.

\subsection{Vegetative vigour and yield}

New shoot length measurements provide a quantitative assessment of a cultivar's investment in new canopy growth, and our results clearly showed this bears a yield cost. Fruit number normalised for flowering intensity and canopy surface area had a negative relationship to new shoot growth ( $R^{2}=0.62$ over both seasons) and new shoot length was strongly $\left(R^{2}=0.80\right)$ and negatively related to normalised yield for the 1990 season (figures 1A, 2B). On the basis of these findings, we accepted the hypothesis that the greater growth of vegetatively vigorous cultivars contributed to lower levels of fruit production in comparison with less vegetatively vigorous cultivars in this tropical environment. The use of the normalising adjustment was an important basis for comparing cultivars as, for example, a cultivar such as Kensington Pride had a large canopy area and also high flowering intensities, but the three-year average fruit numbers for Kensington Pride were lower than for a cultivar such as Irwin, which had a smaller canopy and less intense flowering. The normalisation method included the canopy size and flowering dependency to fruit number or yield of the cultivar and so identified cultivars that have high fruit production per unit of flowering and canopy area. The inclusion of flowering in the normalisation was important as cultivars such as Kensington Pride in this environment can have good flowering intensities but have a poor final fruit number [23], as we also found for Kensington Pride for fruit number per flowering shoot (table $V$ ). Similarly, extreme vegetative vigour associated with low productivity (i.e., low yield per unit of canopy surface area) is also a problem of mango cultivars in tropical environments, including in Australia [6]. Hence, the expression of fruit number or yield based on the intensity of flowering and unit area of canopy provided a value that integrated two important factors affecting mango productivity in the tropics.

A study of 24 Indian mango cultivars (23 monoembryonic and one polyembryonic) found total shoot length was significantly and negatively correlated with average fruit yield per canopy volume across two seasons of one 'on' and one 'off' season [15]. Some aspects of our study were more detailed and our study was the first to our knowledge that showed the extent of new shoot growth in separate seasons had a negative relationship with normalised fruit number and yield. The relationship between 
fruit production and shoot growth had also not been compared across Australian-bred polyembryonic cultivars (Kensington Pride and Strawberry) and Florida-bred monoembryonic cultivars (Haden, Irwin and Tommy Atkins) before.

These findings indicate that resources, possibly photosynthetic assimilate, are limited in mango as cultivars were apparently unable to support both high levels of vegetative growth and fruit production, although these two processes mostly occur at separate times. Further support for interactions between shoot growth and fruit production in mango being affected by resource limitations was found for four biennial-bearing mango cultivars during the peak season of vegetative growth where trees in an 'on' year had shorter shoot lengths than trees in an 'off' year [24]. Studies of assimilate requirements for fruit growth in mango indicate that stored assimilates are important [13]. Starch reserves in young sub-tropical mango trees were shown to be reduced to minimum levels during fruit growth and vegetative flushes that occur at flowering and fruit set were identified as in competition for assimilates [12].

In our study shoot growth measurements were made on 30 terminals per tree over a whole season, and this whole-season growth was compared with whole tree canopy and flowering normalised yields. Once new shoots mature they may be expected to cease being a net sink. However, the trees in our study were young (4-6 years old) and young mango trees have been shown to have greater relative depletions of stored starch following flowering and fruit production than older trees [12]. The shoot growthnormalised fruit number and yield relationships identified in our study indicated a fruit production cost to total seasonal growth. This effect may be due to successive vegetative flushes leaving the young trees with reduced levels of stored assimilates at the start of the flowering and fruiting.

\subsection{Fruit number and yield}

Fruit number for both Haden and Tommy Atkins showed a biennial yield pattern in which they shared a common 'off' year (1989); in contrast, Kensington Pride had two moderate-yielding years and one highyielding year (1990). These cultivar yield patterns were supported by an 18-yearlong study in a wet-dry tropical climate (Mandacaru, Brazil) in which Tommy Atkins and Haden were classified as biennial-bearing, Kensington Pride as erratic, and other cultivars were classified as having an intermediate production pattern [19]. For biennial cultivars, reduced shoot growth has been observed preceding 'on' seasons in comparison with 'off 'seasons [24]. In our study, reduced shoot growth in an 'on' season (1990) was observed for two cultivars (Kensington Pride and Tommy Atkins), but $\mathrm{cv}$. Haden had a large increase in fruit number between 1989 and 1990 that was associated with a non-significant increase in new shoot length. The volume of irrigation affects vegetative growth in mango [25], and a lower than average rainfall preceded the 1990 harvest (1989-1990 wet season, $536 \mathrm{~mm}$ below average, and only $65 \mathrm{~mm}$ of rain over September, October and November, (table I). However, the length of the wet season or rainfall volume was not consistently associated with seasonal differences in shoot growth or fruit number among cultivars. The consistency of fruit number values for Irwin across the three seasons was important given the propensity of some mango cultivars for biennial yielding patterns [26].

Cultivars in this seasonally wet-dry tropical environment study had different yielding patterns to those in other regions of Australia. The yield of Irwin was considered inadequate for further selective evaluations when grown in a dry tropical climate (Bowen, Queensland) [18]. In contrast, a four-year trial comparing 37 cultivars in the same region as our study (Darwin, Northern Territory) reported that 16 cultivars produced over $10 \mathrm{t}$ fruit $\mathrm{ha}^{-1}$ in all seasons including Haden, Kensington Pride and Irwin, but Irwin was one of only five cultivars reported to have consistent levels of fruit production [20]. The importance of genotype by environment interactions among mango cultivars grown in different regions of Australia has also been recently confirmed [27]. These 
differing performances in different regions of Australia highlight the need for developing mango cultivars for specific climates [8, 28]. A physiological study of the same trees as those in this study showed that the net photosynthesis rate of the $\mathrm{cv}$. Irwin was the most suited to the wet-dry tropical growing conditions [11]. The ability of Irwin to maintain higher levels of photosynthesis during the dry season, when fruit production occurs, also implicates the role of assimilate availability as a factor affecting productivity.

In conclusion, our study showed that the greatest vegetative vigour was associated with polyembryonic cultivars, and the extent of shoot growth had a negative relationship with both normalised fruit number and yield. As most shoot growth occurs outside of the flowering and fruit production period, the relationships indicate that shoot growth affects resources, probably stored assimilate, important to later fruit production. New shoot length may be a useful selection criterion for improved productivity of mango in wet-dry tropical environments.

\section{References}

[1] Davenport T.L., Reproductive physiology, in: Litz R.E. (Ed.), The mango, CAB Int., Wallingford, U.K., 2009.

[2] Spreer W., Ongprasert S., Hegele M., Wunsche J.N., Muller J., Yield and fruit development in mango (Mangifera indica L. CV. Chok Anan) under different irrigation regimes, Agric. Water Man. 96 (2009) 574-584.

[3] Anon, Year Book Australia 2009-10, Aust. Bureau Stat. Canberra, Aust., 2009.

[4] Leonardi J., Blaikie S.J., Muller W.J., Scott N.S., Chacko E.K., Effect of cincturing and chemical treatments on growth, flowering and yield of mango (Mangifera indica L.) cv. Kensington Pride, Aust. J. Exp. Agric. 39 (1999) 761-770.

[5] Bally I.S.E., Harris M.A., Foster S., Yield comparisons and cropping patterns of Kensington Pride mango selections, Aust. J. Exp. Agric. 42 (2002) 1009-1015.

[6] Crane J.H., Bally I., Mosqueda-Vaquez R.V., Tomer E., Crop production, in: Litz R.E. (Ed.), The mango, CAB Int., Wallingford, U.K., 1997.
[7] Lu P., Chacko E., Effect of water stress on mango flowering in low latitude tropics of Northern Australia, Acta Hortic. 509 (2000) 283-289.

[8] Iyer C.P.A., Dinesh M.R., Advances in classical breeding and genetics in mango, Acta Hortic. 455 (1997) 252-267.

[9] Scholefield P.B., Oag D.R., Sedgley M., The relationship between vegetative and reproductive development in the mango in Northern Australia, Aust. J. Agric. Res. 37 (1986) 425433.

[10] Gonzalez A., Blaikie S.J., Seasonal variation of carbon assimilation in mango (cv. Kensington Pride): effect of flowering treatments, Aust. J. Agric. Res. 54 (2003) 309-321.

[11] Lu P., Chacko E.K., Bithell S.L., Schaper H., Wiebel J., Cole S., Müller W.J., Photosynthesis and stomatal conductance of five mango cultivars in the seasonally wet-dry tropics of northern Australia, Sci. Hortic. 138 (2012) 108-119.

[12] DavieS.J.,StassenP.J.C., Grove H.G., Starch reserves in the mango tree, Acta Hortic. 509 (2000) 335-346.

[13] Chacko E.K., Reddy Y.T.N., Ananthanarayanan T.V., Studies on the relationship between leaf number and area and fruit-development in mango (Mangifera indica L.), J. Hortic. Sci. 57 (1982) 483-492.

[14] McFadyen L.M., Robertson D., Sedgley M., Kristiansen P., Olesen T., Post-pruning shoot growth increases fruit abscission and reduces stem carbohydrates and yield in macadamia, Ann. Bot. 107 (2011) 993-1001.

[15] Kurian R.M., Iyer C.P.A., Contribution of morphological growth components towards canopy development in mango (Mangifera indica L.), Gartenbauwiss. 62 (1997) 202206.

[16] Ngo H., Owens G., The profitability of mango production in the Top End, Dep. Prim. Ind. Fish., North. Territ. Gov., Tech. Bull. 301, Aust., 2002.

[17] Williams J., Day K.J., Isbell R.F., Reddy S.J., Soils and climate, in: Muchow R.C. (Ed.), Agro-research for the semi-arid tropics: North-West Australia, Univ. Qld. Press, St Lucia, Aust., 1985.

[18] Beal P.R., Screening of mango varieties at Bowen, Queensland, Qld. J. Agric. Anim. Sci. 38 (1981) 71-85.

[19] Souza M.P. de, Queiroz M.A. de, Possidio E.L. de, Pereira F.A., Nunes R.F.D., Study of flowering and alternate bearing of mango 
varieties in the Sao Francisco valley, Acta Hortic. 645 (2004) 353-358.

[20] Scholefield P.B., Baker I.W., Alexander D.M., Flowering, maturity time, production and fruit characteristics of mango cultivars in the Northern Territory, Proc. 1st Aust. Mango Res. Workshop, CSIRO (Melbourne), Cairns, Qsl., Aust., 1984.

[21] Whiley A.W., Rasmussen T.S., Saranah J.B. Wolstenholme B.N., Effect of temperature on growth, dry-matter production and starch accumulation in 10 mango (Mangifera indica L.) cultivars, J. Hortic. Sci. 64 (1989) 753765.

[22] Mukherjee S.K., Litz R.E., Botany and importance, in: Litz R.E. (Ed.), The mango Botany, production and uses, CABI, Wallingford, U.K., 2009.

[23] Scholefield P.B., Oag D.R., Flowering and fruit set of six cultivars of mango, Proc. 1st Aust. Mango Res. Workshop, CSIRO (Melbourne), Cairns, Qsl., Aust., 1984.
[24] Shaban A.E.A., Vegetative growth cycles of some mango cultivars in relation to flowering and fruiting, World J. Agric. Sci. 5 (2009) 751-759.

[25] Durán Zuazo V.H.D., Pleguezuelo C.R.R., Tarifa D.F., Impact of sustained-deficit irrigation on tree growth, mineral nutrition, fruit yield and quality of mango in Spain, Fruits 66 (2011) 257-268.

[26] Monselise S.P., Goldschmidt E.E., Alternate bearing in fruit trees: A review, Hortic. Rev. 4 (1982) 128-173.

[27] Hardner C.M., Bally I.S.E., Wright C.L., Prediction of breeding values for average fruit weight in mango using a multivariate individual mixed model, Euphytica 186 (2012) 463-477.

[28] Bally I.S.E., Lu P., Johnson P.R., Mango breeding, in: Jain S.M., Priyadarshan P.M. (Eds.), Breeding plantation tree crops: Tropical species, Springer, N.Y., U.S.A., 2009.

\section{La productividad está relacionada negativamente con el crecimiento de las ramas en el caso de cinco cultivos de árboles de mango en un clima tropical con estaciones húmedas y secas del norte de Australia.}

Resumen - Introducción. La productividad del árbol de mango es reducida en las regiones tropicales con estaciones húmedas y secas, donde los programas de mejora necesitan más datos sobre los factores que afectan a la productividad de las plantaciones. Más concretamente, nuestro estudio comprobó una nueva hipótesis, según la cual, entre los cultivos de Australia y Florida, cuanto mayor es el crecimiento vegetativo de los cultivos vigorosos, más débil resulta su producción de fruta en comparación con los cultivos menos vigorosos, en un entorno tropical con estaciones húmedas y secas. Material y métodos. Se llevó a cabo un experimento de campo con los árboles de mango 'Kensington Pride' y 'Strawberry', dos cultivos poliembrionarios, y 'Haden', 'Irwin' y 'Tommy Atkins', tres cultivos monoembrionarios. Resultados. Se registró el crecimiento de las ramas durante dos años; a lo largo de dicho periodo, los cultivos poliembrionarios produjeron ramas nuevas de mayor longitud que los cultivos monoembrionarios; 'Irwin' fue el cultivo menos vigoroso durante los dos años. Entre los cultivos, se mostró una relación negativa entre el número y la producción de frutas nornalizadas (en lo referente a la intensidad de la floración y el volumen del dosel) y el vigor vegetativo, representado por la longitud de las nuevas ramas. Conclusión. Los resultados confirman la hipótesis de que un mayor crecimiento de los cultivos vegetativamente vigorosos contribuiría a una producción menor de frutas en comparación con los cultivos vegetativamente menos vigorosos en un entorno tropical. Se trata del primer estudio que demuestra que la magnitud del crecimiento de las ramas de temporada puede afectar al volumen de producción de los árboles de mango.

Australia / Mangifera indica / rendimiento / vigor / ayos de variedades / poliembrionia / monoembrionia 